\title{
Role of Macroclimatic Parameters on the Oscillation of Major Pest Complex in Summer SRI (Oryza sativa L.)
}

\author{
Dibyendu Mondal $^{1 *}$, Anannya Ghosh ${ }^{1}$, Debashis Roy ${ }^{2}$, Adyant Kumar ${ }^{1}$, \\ Diana Shamurailatpam ${ }^{1}$, Ratikanta Ghosh ${ }^{1}$, Pintoo Bandopadhyay ${ }^{1}$, \\ Shantanu $\mathrm{Jha}^{2}$ and Anurup Majumder ${ }^{3}$
}

${ }^{1}$ Department of Agronomy, ${ }^{2}$ Department of Agricultural Entomology, ${ }^{3}$ Department of Agricultural Statistics, Bidhan Chandra Krishi Viswavidyalaya, Mohanpur 741252, Nadia, West Bengal, India

*Corresponding author

\begin{tabular}{|c|c|}
\hline & A B S T R A C T \\
\hline & \multirow{6}{*}{$\begin{array}{l}\text { Studies were carried out to evaluate the impact of abiotic factors on dominant pest } \\
\text { complex of SRI during summer season of } 2014-15 \text { and } 2015-16 \text { at Instructional Farm, } \\
\text { Jaguli, Bidhan Chandra Krishi Viswavidyalaya (BCKV), Nadia, West Bengal. Multiple } \\
\text { correlation and regression coefficients were also computed to establish the relationship } \\
\text { between weather factors and dominant pest complex (weeds, insects and diseases). Both } \\
\text { maximum and minimum temperatures and total rainfall showed a positive but non- } \\
\text { significant correlation with grass (Echinochloa formosensis), sedge (Cyperus difformis) } \\
\text { and broad leaf (Alternanthera philoxeroides) weed species. Highest mean per cent dead } \\
\text { heart ( } 8.33 \% \text { ) and white head ( } 15.33 \% \text { ) caused by yellow stem borer were encountered at } \\
30 \text { DAT and } 90 \text { DAT respectively. In due course of time, temperature and minimum } \\
\text { relative humidity positively correlated with yellow stem borer infestation in a significant } \\
\text { fashion where the computed ' } r \text { ' values were } 0.662 \text { and } 0.773 \text { respectively. In case of blast } \\
\text { disease, significant positive correlation was registered with minimum relative humidity } \\
\text { (r=0.767). However, rainfall showed non-significant ( } \mathrm{r}=0.291 \text { ) but positive effect on the } \\
\text { sporulation of blast fungus under open field condition. Thus, the salient findings of the } \\
\text { present investigation can be a ready reckoned for the farming community in predicting the } \\
\text { appearance of different pests where they can utilize it in sustainable management of } \\
\text { weeds, insects and diseases culminate economic losses in SRI. }\end{array}$} \\
\hline Keywords & \\
\hline $\begin{array}{l}\text { Abiotic factors, } \\
\text { Weeds, Yellow } \\
\text { stem borer, Blast, } \\
\text { SRI. }\end{array}$ & \\
\hline Article Info & \\
\hline $\begin{array}{l}A c \\
\mathrm{xx} \\
A \mathrm{x} \\
\mathrm{xx}\end{array}$ & \\
\hline & \\
\hline
\end{tabular}

\section{Introduction}

Rice (Oryza sativa L.) is one of the world's most important cereal food grains consumed by about two billion people comprising more than one third of human population who relies on this crop for their daily subsistence. Worldwide, $661.81 \mathrm{mt}$ of rice at an average yield of $3.5 \mathrm{t} \mathrm{ha}^{-1}$ is being harvested from $155.17 \mathrm{~m}$ ha of land annually and producing $21 \%$ of world's food calorie (Adhya, 2010).
Since the commencement of agriculture (about 10,000 years ago), growers had to compete with harmful organisms - animal pests (insects, mites, nematodes, rodents, slugs and snails, birds), plant pathogens (viruses, bacteria, fungi) and weeds (competitive undesirable plants), collectively called pests - for crop products grown for human use and consumption. Food plants of 
the world are damaged by more than 10,000 species of insects, 30,000 species of weeds, 100,000 diseases (caused by fungi, bacteria, viruses and other microorganisms) and 1,000 species of nematodes (Dhaliwal et al., 1996). Productivity of crops grown for consumption is at risk due to the incidence of these pests. It is rather difficult to find a direct cause and effect relationship between any single factor and pest activity because the impact of weather factors on pest is usually compounded. For developing weather-based pest forecasting models, the information on the relationship among the incidence of pests, crop phenology and weather factors are needed. Likewise, certain biological events have been changing in the environment since the last decade under the umbrella of climate change (Kisimoto and Dyck, 1976). Keeping these circumstances in mind, the present study was undertaken to identify the role of weather factors on seasonal dynamics of dominant pests of Summer SRI.

\section{Materials and Methods}

The field experiment was conducted in humid sub-tropics of West Bengal at the Instructional Farm, Jaguli, Bidhan Chandra Krishi Viswavidyalaya (BCKV), Mohanpur, Nadia during summer season of 2014-15 and 2015-16 with rice variety Shatabdi (IET4786) to assess the impact of abiotic factors on dominant pest complex of summer SRI. Three quadrants of one $\mathrm{m}^{2}$ were randomly selected from each of $20 \mathrm{sq}$ m plot. From each quadrant, four hills were selected for counting dead hearts or white ear heads at 10 days interval starting from 30 DAT. The weed biomass was recorded species wise using 50 $\mathrm{cm} \times 50 \mathrm{~cm}\left(0.25 \mathrm{~m}^{2}\right)$ quadrate from three randomly selected places in each plot. The collected weed floras from each plot were identified and oven dried at $60 \pm 2^{\circ} \mathrm{C}$ till a constant weight was obtained. The severity of the diseases was recorded on five randomly selected plants of each plot using the PDI rating scales as suggested by IRRI (1988). After scoring the dominant disease, PDI was calculated. To study the effect of major abiotic factors viz., average temperature, maximum and minimum relative humidity, total rainfall and bright sunshine hours on dominant pest infestation, correlation coefficient and multiple linear regression were worked out by taking per cent dead hearts or white ear heads, percent disease index and weed biomass as dependent variable with the mean meteorological data as independent variables.

Analysis of data was performed using statistical software SPSS version 20. Meteorological data were recorded from the Automated Weather Station situated at Jaguli under Bidhan Chandra Krishi Viswavidyalaya, West Bengal, India.

\section{Results and Discussion}

\section{Pest Dynamics}

During the experimentation period, the observed dominant weed species were comprised of grasses (Echinochloa formosensis), sedges (Cyperus difformis) and broad leaves (Alternanthera philoxeroides) while, major insect and disease pests were encountered as yellow stem borer (Scirpophaga incertulas) and blast disease caused by Pyricularia oryzae respectively.

\section{Influence of weather factors on weed pest infestation}

Results revealed that there was a positive significant correlation between the average relative humidity and all the major three different categories of weeds (Echinochloa formosensis, Cyperus difformis and Alternanthera philoxeroides) (Tables 1 and 2 ). In case of other two weather factors, the 
maximum and minimum temperature and total rainfall showed positive but not significant correlation. The correlation coefficient between the average relative humidity and major three weeds was 0.849 in Echinochloa formosensis, 0.862 in Cyperus difformis and 0.828 in Alternanthera philoxeroides. The similar values for maximum temperature with the aforesaid weed species were $0.522,0.599$ and 0.591 respectively and the corresponding figures for rainfall were $0.574,0.563$ and 0.509 respectively.

Average relative humidity positively and significantly correlated with weed species may be due to the influence of varied relative humidity $(68.05 \%$ to $80.45 \%)$ on the growth and development of these three major weed flora. For other two factors rainfall (moisture status) and temperature, the correlation was also positive but not significant as variations of these two factors were less during experimental period.

\section{Influence of weather factors on yellow stem borer infestation}

The per cent dead heart (DH) or white head (WH) of yellow stem borer positively correlated (Table 3 and 4) with average temperature, total rainfall and relative humidity (maximum and minimum) while, negative correlation was observed with bright sunshine hour. During the second fortnight of May (90 DAT) when the average temperature was $27.7^{\circ} \mathrm{C}$ and minimum relative humidity was $60.7 \%$, the $\mathrm{WH}$ per cent was maximum $(15.33 \%)$ whereas, DH was minimum $(8.33 \%)$ in case of average temperature $\left(24.7^{\circ} \mathrm{C}\right)$ and minimum relative humidity $(48.35 \%)$ at 30 DAT of the rice crop. The result is also at par with the findings of Hugar et al., (2010) who observed the highest percentage of $\mathrm{DH}$ during first fortnight of February.
The positive significant correlation of $\mathrm{WH}$ or DH (\%) with temperature $(\mathrm{r}=0.662)$ and minimum relative humidity $(\mathrm{r}=0.773)$ showed their importance on the infestation of yellow stem borer in SRI. This finding was corroborated with the finding of Kumar and Sudhakar (2001). Impact of rainfall on incidence of DH or WH was non-significant $(r=0.297)$ but showed positive effect as the per cent dead heart $(8.33 \%)$ was low when total amount of rainfall was $11.0 \mathrm{~mm}$.

The outbreak of S. incertulas $(15.33 \% \mathrm{WH})$ was noticed when there was $13.8 \mathrm{~mm}$ of total rainfall. Non-significant relationship of total rainfall with that of $\mathrm{DH}$ or $\mathrm{WH}$ was also registered by Hugar et al., (2010) who conceded that significant WH was observed at the time of no rainfall. However, sunshine hours showed non-significant and negative correlation with this insect pest infestation ( $r=$ -0.221). When all the abiotic factors were analysed to find out multiple regression equation, taking dead hearts and white ear heads together as a dependent variable and weather factors as independent variables it could explain that 86 per cent of total variation in the incidence of stem borer.

\section{Influence of weather factors on blast disease infestation}

The impact of major abiotic factors on the incidence of PDI as infected by Pyricularia oryzae at ten days interval during summer season are given in table 3 and 4 . The PDI showed positive correlation with average temperature $(\mathrm{r}=0.65)$, which was evident from higher PDI (39.9\%) that occurred during second fortnight of May when the average temperature was $27.7^{0} \mathrm{C}$ while, with decrease in average temperature $\left(24.7^{0} \mathrm{C}\right)$ the PDI was low $(4.37 \%)$ and that occurred during second fortnight of March. The PDI recorded significant positive correlation with minimum relative humidity $(\mathrm{r}=0.767)$. 
Table.1 Influence of weather factors on the biomass of dominant weed species under different classes of weed in summer SRI (Mean data of two years)

\begin{tabular}{|c|c|c|c|c|c|c|c|}
\hline \multirow{2}{*}{$\begin{array}{l}\text { Days after } \\
\text { transplanting }\end{array}$} & \multicolumn{3}{|c|}{ Weed biomass $\left(\mathrm{g} \mathrm{m}^{-2}\right)$} & \multicolumn{2}{|c|}{ Temperature $\left({ }^{0} \mathrm{C}\right)$} & \multirow{2}{*}{$\begin{array}{c}\text { Total } \\
\text { rainfall } \\
(\mathbf{m m})\end{array}$} & \multirow{2}{*}{$\begin{array}{c}\text { Average relative } \\
\text { humidity }(\%)\end{array}$} \\
\hline & E. formosensis & C. difformis & A. philoxeroides & Maximum & Minimum & & \\
\hline 30 & 32.23 & 42.8 & 7.99 & 32.23 & 17.11 & 11.00 & 69.45 \\
\hline 40 & 34.32 & 46.12 & 8.23 & 34.32 & 19.89 & 0.00 & 68.05 \\
\hline 50 & 33.78 & 60.63 & 12.82 & 33.78 & 21.84 & 36.00 & 80.45 \\
\hline 60 & 34.84 & 64.85 & 15.47 & 34.84 & 22.53 & 7.00 & 74.00 \\
\hline 70 & 33.82 & 74.3 & 16.15 & 33.82 & 20.84 & 35.10 & 79.90 \\
\hline 80 & 34.50 & 78.36 & 17.12 & 34.50 & 21.12 & 20.00 & 80.05 \\
\hline
\end{tabular}

Table.2 Correlation and regression coefficient values for biomass of Echinochloa formosensis, Cyperus difformis and Alternanthera philoxeroides with respect to weather parameters in summer SRI

\begin{tabular}{|c|c|c|c|c|c|}
\hline \multirow{2}{*}{ Weed pest } & \multirow{2}{*}{ Particulars } & \multicolumn{2}{|c|}{ Temperature $\left({ }^{0} \mathrm{C}\right)$} & \multirow{2}{*}{$\begin{array}{l}\text { Total rainfall } \\
(\mathrm{mm})\end{array}$} & \multirow{2}{*}{$\begin{array}{c}\text { Average relative } \\
\text { humidity }(\%)\end{array}$} \\
\hline & & Maximum & Minimum & & \\
\hline \multirow{3}{*}{ Echinochloa formosensis } & Correlation coefficient & 0.522 & 0.612 & 0.574 & $0.849 *$ \\
\hline & Regression coefficient & 14.821 & -7.017 & -0.144 & 3.380 \\
\hline & $\mathrm{R}^{2}$ & \multicolumn{4}{|c|}{0.918} \\
\hline \multirow{3}{*}{ Cyperus difformis } & Correlation coefficient & 0.599 & 0.675 & 0.563 & $0.862 *$ \\
\hline & Regression coefficient & 8.952 & -4.047 & -0.398 & 3.557 \\
\hline & $\mathrm{R}^{2}$ & \multicolumn{4}{|c|}{0.919} \\
\hline \multirow{3}{*}{ Alternanthera philoxeroides } & Correlation coefficient & 0.591 & 0.736 & 0.509 & $0.828 *$ \\
\hline & Regression coefficient & 0.265 & 0.026 & -0.211 & 1.060 \\
\hline & $\mathrm{R}^{2}$ & \multicolumn{4}{|c|}{0.877} \\
\hline
\end{tabular}


Table.3 Influence of weather factors on the infestation of yellow stem borer (Scirpophaga incertulas) and blast disease pest of rice in summer SRI (Mean data of two years)

\begin{tabular}{|c|c|c|c|c|c|c|c|}
\hline \multirow{2}{*}{$\begin{array}{l}\text { Days after } \\
\text { transplanting }\end{array}$} & \multirow{2}{*}{$\begin{array}{c}\text { Stem Borer } \\
\text { Dead heart or } \\
\text { White head (\%) }\end{array}$} & \multirow{2}{*}{$\begin{array}{c}\text { Blast } \\
\text { Percent disease } \\
\text { index (PDI) }\end{array}$} & \multirow{2}{*}{$\begin{array}{c}\text { Average } \\
\text { temperature } \\
\left({ }^{0} \mathrm{C}\right)\end{array}$} & \multicolumn{2}{|c|}{ Relative humidity (\%) } & \multirow{2}{*}{$\begin{array}{l}\text { Total rainfall } \\
\quad(\mathbf{m m})\end{array}$} & \multirow{2}{*}{$\begin{array}{c}\text { Bright } \\
\text { sunshine hour } \\
\left(\text { hr } \text { day }^{-1}\right)\end{array}$} \\
\hline & & & & Maximum & Minimum & & \\
\hline 30 & 8.33 & 4.37 & 24.67 & 90.55 & 48.35 & 11.00 & 8.39 \\
\hline 40 & 10.09 & 10.45 & 27.10 & 86.09 & 50.00 & 0.00 & 9.28 \\
\hline 50 & 11.08 & 17.56 & 27.81 & 95.80 & 65.10 & 36.00 & 7.86 \\
\hline 60 & 12.58 & 25.84 & 28.69 & 90.40 & 57.60 & 7.00 & 6.91 \\
\hline 70 & 14.50 & 32.74 & 27.33 & 90.20 & 69.60 & 35.10 & 7.86 \\
\hline 80 & 15.10 & 36.14 & 27.81 & 90.70 & 69.40 & 20.00 & 8.73 \\
\hline 90 & 15.33 & 39.90 & 27.70 & 92.30 & 60.70 & 13.80 & 7.89 \\
\hline
\end{tabular}

Table.4 Correlation and regression coefficient values for average dead heart or white head infestation and percent disease index (PDI) of blast disease with respect to weather parameters in summer SRI

\begin{tabular}{|c|c|c|c|c|c|c|}
\hline \multirow{2}{*}{ Pests } & \multirow{2}{*}{ Particulars } & \multirow{2}{*}{$\begin{array}{c}\text { Average } \\
\text { temperature } \\
\left({ }^{0} \mathrm{C}\right)\end{array}$} & \multicolumn{2}{|c|}{ Relative humidity (\%) } & \multirow{2}{*}{$\begin{array}{c}\text { Total } \\
\text { rainfall } \\
(\mathbf{m m})\end{array}$} & \multirow{2}{*}{$\begin{array}{c}\text { Bright sunshine } \\
\text { hour } \\
\left(\text { hr } \text { day }^{-1}\right)\end{array}$} \\
\hline & & & Maximum & Minimum & & \\
\hline \multirow{3}{*}{ Stem borer } & Correlation coefficient & 0.662 & 0.124 & $0.773 *$ & 0.297 & -0.221 \\
\hline & Regression coefficient & -0.296 & 0 & 0.478 & -0.182 & -0.453 \\
\hline & $\mathrm{R}^{2}$ & & & 0.863 & & \\
\hline \multirow{3}{*}{ Rice blast } & Correlation coefficient & 0.65 & 0.228 & $0.767 *$ & 0.317 & -0.328 \\
\hline & Regression coefficient & -2.676 & 0.643 & 2.57 & -1.079 & -4.167 \\
\hline & $\mathrm{R}^{2}$ & & & 0.861 & & \\
\hline
\end{tabular}

*indicate significant of values at $\mathrm{P}=0.05$ 
The PDI was maximum (39.90\%) during second fortnight of May when minimum relative humidity was 60.70 per cent. The present findings are in conformity with the findings of Kapoor and Kaundal (2007) who reported the significant effect of temperature and relative humidity on the incidence of rice blast. Impact of rainfall on incidence of blast disease of rice was nonsignificant $(r=0.291)$ but showed positive effect which is in parity with the findings of Prasad et al., (2015). However, bright sunshine hours showed non-significant and negative correlation with PDI $(r=-0.314)$. Multiple regression analysis revealed that weather parameters have highly significant effects $(\mathrm{P} \leq 0.05)$ on the per cent disease index of blast disease of rice confirming the results of correlation analysis.

The correlation and multiple regression analysis clearly depict the importance of weather parameters in the incidence of different pests (weed, insect and disease) and their relative effects on SRI. These findings can be used to predict the initiation and peak incidence of the pest attack which will serve as a database for the farming community to adopt effective eco-safe protection measures at the appropriate time. Forecasting the peak abundance of dominant pests in advance will help the SRI farmers in timely management during the critical crop pest competition period to curb the infestation below the ETL. Minimizing losses from these major pests can enable the paddy cultivators to increase the productivity in a sustainable manner to the desired level. Thus the investigated result of the experiment may also help the farmers to strategize their crop protection plan accordingly in summer SRI in the light of individuals' resource affordability.

\section{Acknowledgement}

The authors are thankfully acknowledged to the Head, Department of Plant Pathology, Bidhan
Chandra Krishi Viswavidyalaya, for his technical guidance in this research work. Authors are also grateful to Directorate of Farms, Bidhan Chandra Krishi Viswavidyalaya, for allotting the field in order to conduct the concerned research.

\section{References}

Adhya, T.K., 2010. Imparting climate resilience in rice. The Hindu Survey of India. Pp. 24-27.

Dhaliwal, G.S., and Arora, R. 1996. Principles of insect management, Pp 35-75, Commonwealth Publisher. USA.

Hugar, S.V., Hosamani, V., Hanumanthaswami, B.C. and Pradeep, S. 2010. Influence of weather factors on the infestation of yellow stem borer, Scirpophaga incertulas Walker in aerobic rice. Asian Journal of Environmental Science. 4: 151-154.

IRRI, 1988. Standard Evaluation System for Rice. International Rice Research Institute, Annual report, 1988-89, International Rice Research Institute, Philipines. Pp. 48.

Kapoor, A.S., and Kaundal, R. 2007. Development of weather based forewarning systems for rice blast. Himachal Journal of Agricultural Research. 33 (2): 211-217.

Kisimoto, R., and Dyck, V.A. 1976. Climate and rice insects. On climate and rice, held in September 1975, International Rice Research Institute, Manila. Pp. 367-391.

Kumar, A.D.V.S.L.P.A., and Sudhakar, T.R. 2001. Incidence of the yellow stem borer, Scirpophaga incertulas (Walker), on rice in relation to weather parameters. Pest Management and Economic Zoology. 9(2): 161-164.

Prasad, R., Sharma, A. and Sehgal, S. 2015. Influence of weather parameters on occurrence of rice blast in mid hills of Himachal Pradesh. Himachal Journal of Agricultural Research. 41: 132-136.

\section{How to cite this article:}

Dibyendu Mondal, Anannya Ghosh, Debashis Roy, Adyant Kumar, Diana Shamurailatpam, Ratikanta Ghosh, Pintoo Bandopadhyay, Shantanu Jha and Anurup Majumder. 2017. Role of Macroclimatic Parameters on the Oscillation of Major Pest Complex in Summer SRI (Oryza sativa L.). Int.J.Curr.Microbiol.App.Sci. 6(10): 445-450. doi: https://doi.org/10.20546/ijcmas.2017.610.054 